Research:

\title{
THE INFLUENCE OF GOOD CORPORATE GOVERNANCE AND AUDIT QUALITY AGAINST THE DISCLOSURE OF CORPORATE SOCIAL RESPONSIBILITY
}

\author{
By: \\ Darwin Marasi Purba \\ Lecturer at STIE Binaniaga Bogor
}

\begin{abstract}
This study aimed to get empirical evidence about the influence of good corporate governance consists of the proportion of institution ownership, board size, the proportion of independent commisioners, audit committee size and audit quality on the disclosure of corporate social responsibility with leverage as control variables.

Population of this research are manufacturing companies listed in Indonesia Stock Exchange in 2014 the annual report contains disclosure of corporate social responsibility activities of companies which some 59 companies using purposive sampling technique. Methods of data analysis using descriptive statistical analysis and multiple linear regression.

These results indicate that good corporate governance and audit quality has a significant effect simultaneously on the disclosure of corporate social responsibility of the company. However, partial test results showed that the proportion of institutional ownership, board size, the size of the audit committee and audit quality is not affected by the disclosure of corporate social responsibility. While the proportion of independent commisioners have a negative significant effect on the disclosure of corporate social responsibility.
\end{abstract}

Keyword: good corporate governance, corporate social responsibility disclosure.

\section{INTRODUCTION}

Since mid of 1997 Indonesia has been suffered the worst and the longest economics crises (Hapsoro, 2012). One of the main reasons why it happened in Indonesia quite long is due to the weakness of law enforcement and corporate governance implementation. Implementing corporate governance is one of the significant efforts to get rid of the crises in Indonesia (Suherman et al., 2011). The implementation of good corporate governance principles is one of the most important factors to be considered by some foreign investors and creditors before making a decision to invest their capital.

Corporate governance is a chain of mechanism to equalize an action and a choice of the manager with the stakeholders need harmoniously based on the fifth principles; fairness, transparency, accountability, independency and responsibility. (Kallunki et al. , 2011). Good Corporate Governance (GCG) is an elaboration of the agency theory that has tried to describe the people involved in the company (managers and the owner of the company) to behave in a proper way since they have their own interest differently.

Weakness of GCG implementation has been reflecting to the result of the company objectives which is unable to maximize the profit, to develop the company facing its business competition, to satisfy the stakeholders requirements. (Ribstein, 2005). GCG is a concept to fulfill the requirements of the stakeholder properly which is the accurate information to be received on time. The company has obliged to disclose all the company performance accurately. (Ramanarayanan \& Snyder. 2012).

Indonesia has been implementing the GCG principles after signing the Letter of Intent (LOI) with the International Monetary Fund (IMF). The National Committee of Corporate Governance Policy (KNKCG) has declared that all the companies in Indonesia have to implement the standard of GCG International. One of the GCG principles is that the company should have to be concerned with the society and the environtment accordingly refers to the responsibility principles (Ryngaert \& Buchanan, 2011). Responsibility principles defined that the important role of the stakeholders are 
their existency. Stakeholders refer to a party which is aware of the existency of their company, employees, customers, consumers, societies nearby and the government as a regulator.

There are so many public complaints have come up refers to the environment contamination, unfair treatment for minority and women workers, authority misusage, security, product quality, exploitation of natural and energy resources. Those facts have been explaining that there are still many public companies that have not implemented yet the CGC principles properly. Based on the aforementioned matters, GCG responsibily principles have delivered a corporate social responsibility (CSR) to be applied by the company respectfully as the company responsibility (De Graff \& Stoelhorst, 2010).

It is not only the corporate governance aspect but CSR concept has involved the role of independent auditors to qualify the inspection. The big public accountant enterprises usually have a better reputation and experiences than the small public accountant offices. According to Susiana and Arleen Herawaty (2007) the big four of KAP (Public Accountant Enterprise) are more reliable to avoid things that could jeopardize their reputation rather than the non big four of KAP. Therefore, its independent auditors have strong willingness to keep their good reputation in relation with the evaluation of the CSR information disclosure.

The reason why some companies have declared their CSR information voluntarily because they have respected the applicable regulations and to obtain a perfect competitiveness through the CSR implementation; to be in compliance with a credit contract and to deliver the society expectation; to legitimate the activitiy of the company and to invite the investor. Eventhough, it has not ben yet an obligation but almost all the companies registered in BEI (Indonesia Stock Exchange) have disclosed the CSR information accordingly in their annual report.

The components that have been used to analze the corporate social responsibily index, they have adopted the Global Reporting Index (GRI) G4 version, so that they could provide a better information to the market and society regarding the related sustainable problems. G4 has described the procedures to be applied either by big organizations or small ones worldwide. GRI guidelines, G4 has indicated the references of reporting documentation in relation with a certain problem which is accepted in general and is able to be applied globally by any kind of organization refers to a consolidated framework to provide a continuous work performance reporting.

\section{REVIEW OF LITERATURE}

Gray et.al (1986, in Nor Hadi, 2011:88) described that legitimation is a company management system that has orientated to the society, government, individual, and community.

Legitimation theory is based on the understanding about social contract that has been applied between the social institution and the society (Ahmad and Sulaiman, 2004). A company which is as a part of the society usually has been influencing its surroundings. Therefore, the company through its top management has tried to be in compliance with the value of the company and the value of the society in general as well as the related public or its stakeholders. (Guthrie \& Ward, 2006).

The disclosure of the Corporate Social Responsibility in the Annual Report is one of the company's effort to evolve, to maintain and to legitimate the contribution of the company economically and politically. When the company has been accepted by the society, it is expected to be able to increase the value of the company due to the profit increasing. It explains that it could be able to invite the potential investors to invest their money.

\section{Agency Theory.}

Agency theory is about the relationship between two parties where one or more principals have appointed another party as an agent to execute any service on behalf of the company which is the delegation of the authority given by the company. (Jensen and Meckling, 1976).

Corporate Governance is able to reduce any potential cost of an agency. The agency cost that has come up due to a conflict of interest occurred between an agent and principal could be reduced by applying a controlling system that could manage the requirements of the company. (Rustiarini, 2010). Good Corporate Governance (GCG) mechanism is considered could reduce the problems with the agency refers to the managers' behavior that has a tendency to hide some 
information for the sake of their own benefit and GCG mechanism is able to increase the disclosure of the company.

\section{Corporate Social Responsibility (CSR).}

Corporate Social Responsibility is the commitment of the company to contribute their effort in a continuous economy development which is their social awareness regarding to economics, socials, and environments aspects (Untung 2008:1)

CSR development is related to the damage of the environment in Indonesia as well as worldwide more and more refers to forestry exploitation, air and water polluted, climate changed. The live of the companies could only happen when they are fully aware of the social and environmental aspect, but people will be reject a company when it does not care about the aspect of social, economy and environment.(Nurlela and Islahudin, 2008)

\section{Corporate Governance.}

The study of the Corporate Governance Study has been discussed for the first time by Berle and Means in 1932 when a book analyzing the separation between shareholders and management. National Committee of Governance Policy (KNKG, 2004) has described that corporate governance is the process and structure being used by the organization of a company to give a continuous value-added for the company and in compliance with the requirements of other stakeholders based on the applicable regulation and norms. De Cleyn (2008) considered that corporate governance is a chain of system, process and regulation which has been managing the relationship among the related parties accordingly.

Based on the aforementioned definitions, corporate governance is a chain of regulations managing the relationship of various parties in the company which is related to the company's rights and obligations to achieve its objective to fulfil the requirements of the stakeholders but still considering all parties needs.

\section{Commissioner Board.}

Egon Zehnder International (2000) defined that a commissioners board is the key of corporate governance to execute and to guarantee that the implementation of the company's strategy has been applied accordingly which is to supervise the management to run the company and to achieve its accountability properly. An independent commissioners have been regulated by BEI based on Regulation of BEJ on $1^{\text {st }}$ of July 2000. The aforementioned regulation has defined that the member of the independent commissioners board is $30 \%$ minimum. The regulation has influenced the controlling and supervising the management to disclose the corportate social responsibility.

\section{Audit Committee.}

An audit committee has a separate task to assist the commissioner board responsibilitgy to execute its supervision overall (Carcello et al, 2011). The Institute of Internal Auditors (IIA) has recommended that each public company should have an audit committee as a permanent committee.

IIA has declared that an audit committee is consisting of independent commissioners which are free of daily management activities and have a main responsibility to assist the commissioners board to execute their responsibilities relating to the problems occurred in the company refers to the accountancy policy, internal controlling, and financial reporting systems.

\section{Audit Quality.}

De Angelo (in Alim, 2007) has defined that an audit quality is a probability where an auditor could be able to discover and report that a violation has happened in the accounting system of the clients. Company Financial Report which has been audited by the big four of the Public Accountant Office (KAP) must be more reliable and better quality instead of non-big four KAP audited. It is believed that the big-four KAP could provide an independent and clear audit service to disclose any misstatement mentioned on the company financial report. 


\section{Frame work.}

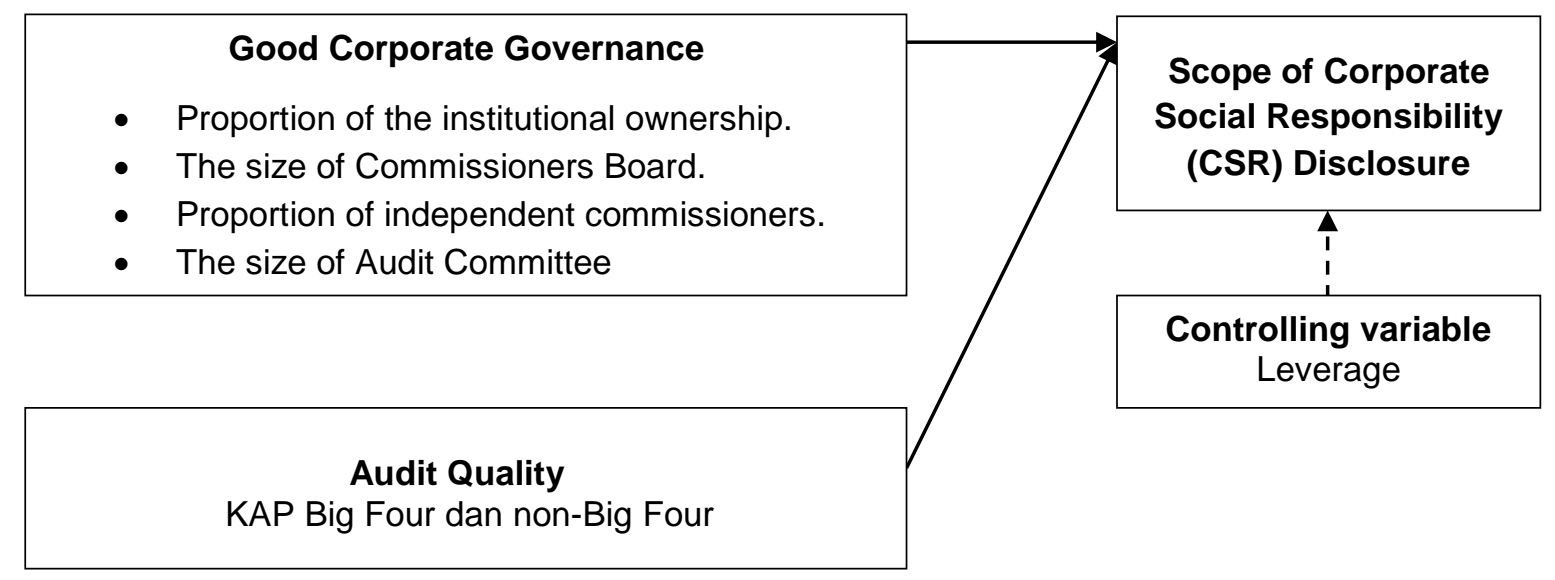

Picture 1

Framework of the Reserach

\section{HYPOTHESIS}

\section{The influence of the proportion of the Institutional Ownership against the CSR Disclosure.}

Anggraini (2006) defined that the company is obliged to provide a transparent information, accountable organization, and GCG has forced the company to provide an information about its social activities accordingly. The Institutional Ownership is company's shares belong to a financial institution such as, insurance company, bank and pension funds (Koh, 2003). The more the institutional ownership the higher level of controlling could be done by the investor to avoid any misconducted behavior of the manager. The institutional ownership of the company which is more than $5 \%$ has been able to indicate and to monitor the management accordingly. The disclosure CSR is one of the company's activities being monitored by the institutional ownership of the shares. Therefore, a hypothesis has been designed as follows:

Based on the aforementioned explanation, a hypothesis that will be evaluated;

$\mathrm{H}_{1}=$ the proportion of the institutional ownership which is having a positive influence to the disclosure of its CSR.

\section{The influence of the Commissioners Board size against the Disclosure of its CSR.}

Commissioners board is the highest level of the internal controlling system within the company having the power to define a company policy including the practice and disclosure of its CSR.

Akhtaruddin, et.al (2009) has concluded that the more commissioners board members are the better experience and expertise the company would get which is reflecting to CSR disclosure since it could reduce the managers' opportunity to hide some information required.

$\mathrm{H}_{2}=$ Commissioners board size has a positive influence to the disclosure of its CSR.

The influence of the proportion of independent commissioners against the Disclosure of its CSR.

The composition of independent commissioner board has been considered as a solution to handle the agency problem. Foker research (within Said, et.al, 2009) defined that the existency of the independent commissioner board could be able to force the commissioner board to make a decision objectively to protect the management from the violation of an agent.

Therefore, the objective of the company to get a legitimate from the stakeholders could be achieved by disclosing that the social responsibility of the company could be obtained accordingly because of the existency of the independent commissioner board that will be controlling and supervising it. Hence, the hypothesis is as follows: 
$\mathrm{H}_{3}=$ The proportion of the independent commissioner has a positive influence against the disclosure of its CSR.

\section{The influence of the size of audit committee against the disclosure of CSR.}

An audit committee is consisting of independent commissioners who are free from any daily management activities are having in charge of assisting the commissioner board responsibilities. The regulation of the chief of Bapepam number Kep-29/PM/2000 which is on the Regulation No. IX.1.5. describes that an audit committee belongs to the company should be minimum 3 persons, which is at least one person from the independent commissioners and two members are from the external organization or public company.

The availability of audit committee could influence the way how to disclose the company significantly (Ho \& Wong, in Akhtaruddin et. al, 2009). Foker (in Said et.al, 2009) describes that an audit committee has been considered as an effective tool to execute the mechanism of controlling, so that, it could reduce the agency fee and be able to increase the quality of the disclosure of the company information. The hypothesis is as follow:

$\mathrm{H}_{4}=$ The size of audit committee has a positive influence against the disclosure of CSR.

\section{The influence of Audit Quality against the disclosure of CSR.}

Financial Annual Report which has been evaluated by a public accountant could be used as a basic to make an economical decision. A company that has been audited by a big public accountant enterprise has shown a proper financial report refers to the applicable regulation accordingly, as a big public accountant enterprise has better quality, reputation, credibilities than a small public accountant enterprise.

According to Subroto (2002): Hapsoro (2012) described that a higher quality of an audit would be able disclose its CSR in detail in the annual report of the company. A hypothesis will be as follow:

$\mathrm{H}_{5}=$ Quality of an audit has a positive influence against the disclosure of CSR.

\section{RESEARCH METHODOLOGY}

\section{Population and Sampling Procedure.}

The population of this research is the manufacturing companies which are registered in BEI (Indonesia Stock Exchange) in 2014. Sampling technique has applied a purposive sampling method, which is a sampling technique identification refers to a specific consideration (Sugiyono 2014:126). Some criteria relating to sampling application are as follows:

1. Manufacturing companies

2. Companies which have sent their annual report of 2014 to BEI.

3. Companies having a related information with this research.

This research has been applying the slovin' calculation refers to $90 \%$ trustworthy and $10 \%$ precision or $(0.10)$ resulting minimal samples which is 59 companies.

\section{Operational Variable}

\section{Independent Variable}

\section{The proportion of the Institutional Ownership}

Variable of the proportion of the institution ownership (INST) has been measured by dividing the total of shares belongs to the institution with the circulated shares. Total shares owned by the institution is according to its financial reporting.

\section{Commissioner Board Measurement}

Variable of commissioners board (DKOM) has been measured based on the total members of the commissioners board of the company.

\section{Proportion of independent commissioners}

Variable of the proportion of independent commissioners (KIND) has been measured based on the proportion of the members of the independent commissioners against the total members of commissioners board of the company itself. 


\section{The size of an Audit Committee}

Variables of the size of audit committee have been measured by calculating the total member of an audit committee of the company.

\section{Audit Committee}

Variable of audit quality (KUAD) has been defined based on the financial reporting which has been audited by the BigFour accountant enterprise and non-Big Four one. This variable has been measured using dummy variable which is 0 if an auditor were from non-big four accountant enterprise and 1 if an auditor were from Big Four accountant enterprise.

\section{Dependent Variable}

\section{Corporate Social Responsibility}

Dependent variable in this research is the disclosure of social responsibility which has been measured by indicating whether or not any information about the disclosure of its social responsibility has been reported on the company annual reporting. To discover the social responsibility in this research, the researcher has applied the social information category refers to Global Reporting Initiative (GRI) version 4 which is content analysis to classify the CSR disclosure based on the aspects of economic, environmental, labor practices and decent work, human rigts, society and product responsibility. Herebelow is a formula to calculate Corporate Social Responsibility Disclosure Index (CSRDI):

$$
\operatorname{CSRDI}_{j}=\frac{\sum x_{i j}}{n_{j}}
$$

\section{Description:}

CSRDI : Corporate Social Responsibility Disclosure Index company

$n_{j} \quad:$ Total items of the disclosure of the company $j, n_{j}=91$

$\mathrm{x}_{\mathrm{ij}}: \mathrm{x}_{\mathrm{ij}}: 1=$ disclosed item $\mathrm{i} ; 0=$ closed item $\mathrm{i}$.

Therefore, $0<$ CSRDIj $\leq 1$

\section{Controlled variable}

Controlled variable in this research is a leverage showing the company ability to pay its longterm payment or other duties to be settled down when the company is liquidated. Leverage could be calculated based on the following formulation:

$$
\begin{aligned}
& \text { Debt to Equity Ratio } \\
& (\text { DER })
\end{aligned}=\frac{\text { Total Debt } \times 100 \%}{\text { Equity }}
$$

\section{Analysis Method}

This research has applied parametric statistical evaluation. This statistics evaluation aims to give a big picture of sampling data profile. Regression examination is one of parametric statistics evaluation to examine the hypothesis provided in order to examine the determination coefficient test $\left(R^{2}\right)$, simultaneous influences test ( $F$-test) and partial influences test (t-test).

Model of multiple regression is as follows :

$$
\text { CSRDI }=\beta_{0}+\beta_{1} \text { INST }+\beta_{2} \text { DKOM }+\beta_{3} \text { KIND }+\beta_{4} \text { UKAD }+\beta_{5} \text { KUAD }+\varepsilon
$$

Note :

CSRDI

INST

\section{Corporate Social Responsibility Disclosure Index}

DKOM : The size of commissioners board. 


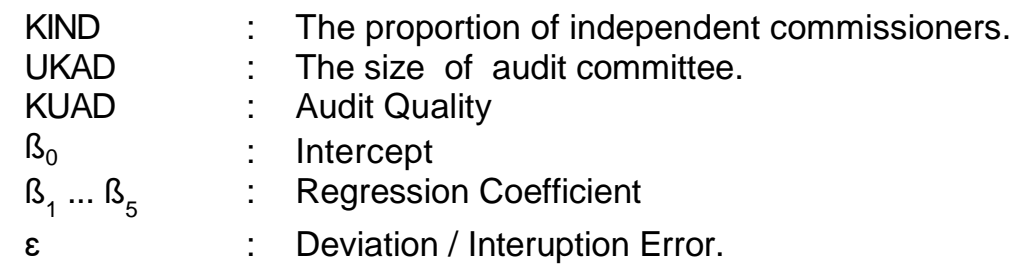

\section{RESULTS AND DISCUSSION}

Tabel 1

Descriptive Statistics Variable of the Research

\begin{tabular}{|l|r|r|r|r|r|}
\hline & $\mathrm{N}$ & Minimum & Maximum & Mean & Std. Deviation \\
\cline { 2 - 6 } & Statistic & Statistic & Statistic & Statistic & Statistic \\
\hline Proporsi Kepemilikan & 59 &, 37 &, 99 &, 7340 &, 15095 \\
Institusional & & & & & \\
Ukuran Dewan Komisaris & 59 & 2 & 11 & 4,32 & 2,046 \\
Proporsi Komisaris & 59 &, 25 &, 60 &, 3693 &, 06800 \\
Independen & & & & & \\
Ukuran Komite Audit & 59 & 2 & 5 & 3,05 &, 391 \\
Kualitas Audit & 59 & 0 & 1 &, 44 &, 501 \\
CSR Disclosure Index & 59 &, 43 &, 92 &, 8034 &, 08166 \\
Leverage & 59 &, 00 & 5,87 & 1,0594 & 1,22656 \\
Valid N (listwise) & 59 & & & & \\
\hline
\end{tabular}

Source : Output SPSS 22.00 (2015)

Table 1 explains that the disclosure index of Corporate Social Responsibility (CSRDI) has an average value of 0.8034 or $80.34 \%$. It explains that the company has a high awareness to disclose the information about the corporate social responsibility accordingly.

Variable of the proportion of the institutional ownership has indicated a mean value of 73.40 $\%$. It explains that at average the companies in Indonesia have been dominated by other institutions. $37 \%$ minimum value and $99 \%$ maximum value have described that most shares of the company have been owned by other institution as well. But the deviation standard is $15.095 \%$.

Variables of the size of commissioners board and the proportion of independent commissioners have identified mean value of 4.32 and $36.93 \%$. It explains that most of the companies in Indonesia have applied the applicable regulation accordingly (Regulation of Bapepam and Policy of the Indonesia Stock Exchange No. 1-A dated on 14 th July 2004, mentioning that the company should have an independent commissioners board at least $30 \%$ ) though, some of the companies are still having the proportion of independent commissioners which is 0.25 or $<30 \%$

Variable of the size of audit committee has identified mean value of 3.05. It means that at average the total member of company audit committee has been in compliance with the rule which is 3 persons. Though, some companies are still having only 2 persons or less than 3 persons as required.

Variable of audit quality has identified mean value of 0.44 . It explains that $44 \%$ manufacturing companies have been audited by the BigFour of Public accountant and the rest $56 \%$ is the companies that have been audited by non BigFour Publc Accountant.

Leverage has identified mean value of 1.0594 and deviation standard of 1.22656 . Both values have identified that at average the companies in Indonesia has a sufficient effort to settle the long-term payments. 
Tabel 2

Description of the disclosure of Corporate Social Responsibility

(Based on the indicator of GRI , G4 version)

\begin{tabular}{|c|c|c|c|c|c|c|c|c|c|c|}
\hline \multirow{2}{*}{ No. } & \multicolumn{2}{|l|}{ SAMPLE } & \multicolumn{8}{|c|}{ the disclosure of Corporate Social Responsibility } \\
\hline & $\begin{array}{l}\text { Company } \\
\text { classification }\end{array}$ & Total & Score & Amount & EC & EN & LA & HR & so & PR \\
\hline 1 & $\begin{array}{l}\text { Primary and } \\
\text { Chemical Industry } \\
\text { sector }\end{array}$ & 26 & 0,63 & 73,23 & 9 & 30,04 & 14,73 & 7,73 & 5,15 & 6,58 \\
\hline 2 & $\begin{array}{l}\text { Sektor Aneka } \\
\text { Industri Various } \\
\text { Industry sector }\end{array}$ & 14 & 0,72 & 70,65 & 8,93 & 27,79 & 13,86 & 8,43 & 5,14 & 6,50 \\
\hline 3 & $\begin{array}{l}\text { Consumers } \\
\text { goods industry } \\
\text { sector }\end{array}$ & 19 & 0,79 & 74,89 & 8,84 & 30,37 & 14,89 & 8,63 & 5,53 & 6,63 \\
\hline & mlah (Rata-Rata) & 59 & 0,71 & 72,92 & 8,92 & 29,4 & 14,49 & 8,26 & 5,27 & 6,57 \\
\hline \multicolumn{4}{|c|}{ The disclosure should be } & 91 & 9 & 34 & 16 & 12 & 11 & 9 \\
\hline \multicolumn{4}{|c|}{ Skor Rata-Rata (\%) } & 80,13 & $\begin{array}{c}99,1 \\
1\end{array}$ & 86,47 & 90,56 & $\begin{array}{c}68,8 \\
3\end{array}$ & $\begin{array}{c}47,9 \\
1\end{array}$ & 73,00 \\
\hline
\end{tabular}

Source: Secondary data - calculated (2015)

Table 2 aforementionned has identified the disclosure indicator of corporate social responsibility based on GRI indicators that contains of 6 catagories; economy, environment, manpower practice and work comfortable, human rights, society and product responsibility that have been in compliance with a sufficient category which is 0.71 scores of $71 \%$. Society theme is the smallest indicator which is $47.91 \%$. Economy theme has indicated $99.11 \%$ scores which is the biggest one. Furthermore, environment theme is $86.47 \%$, manpower practice theme and work comfortable theme is $90.56 \%$, Human right theme is $68.83 \%$ scores, finally products responsibilities is $73 \%$ scores. Consumer goods industry sector has disclosed the activity of its corporate social responsibility 0.79 or $79 \%$ which is the biggest one. Various industry sector is 0.72 or $72 \%$. Primary and chemical industry sectors have disclosed its corporate social responsibility 0.63 or $63 \%$ which is the smallest one. Overall, manufacturing companies in Indonesia have had a fully understanding to disclose its corporate social responsibility activities as the GRI indicator.

\section{Test of the Research Instrument.}

1. Normality Test

$E \sim N(1.0)$ is within the normal distribution when the unstandardize residual scatters are surrounding the diagonal line and in line with it, it concludes that residual value of regression model has had a normal distribution or in compliance with the assumption of normality data. 


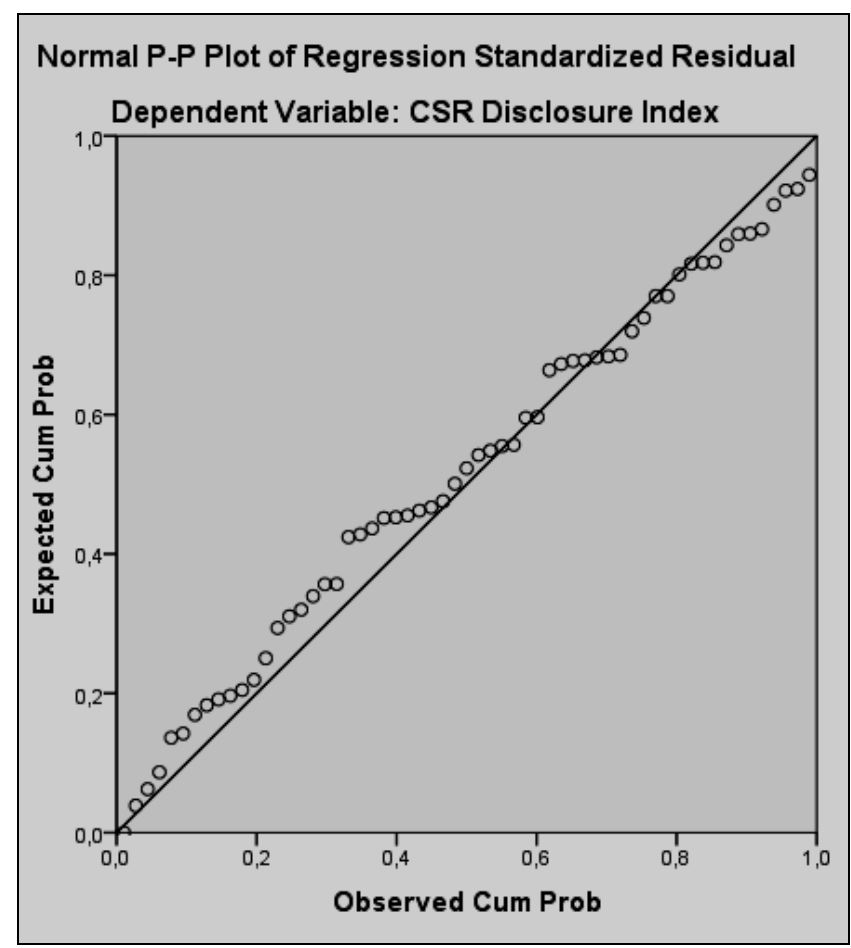

Source: Output SPSS 22.00 (2015)

Picture 2 Result of Normality Test P-Plots

Besides of applying a graph analysis, normality test could be done using KolmogorovSmirnov test. Result of the test is on the table 3 here below.

Table 3 Result of Kolmogorov Smirnov Test

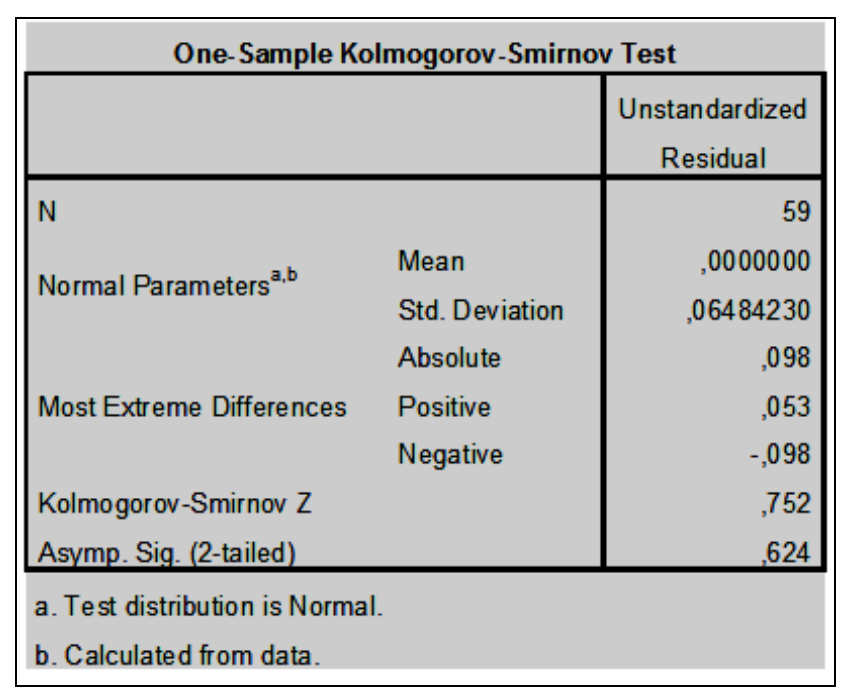

Source: Output SPSS 22.00 (2015)

Result of Kolmogorov-Smirnov test on the table 3 has been applying non-parametric statistic One-sample Kolmogorov-Smirnov refers to the variable of the disclosure of its corporate social responsibility where $p=0.624$, since $p>0.05$ and Ho is accepted, it concludes that residual value is getting along with the function of its normal data distribution. 


\section{Heteroskedastisity}

Heteroskedastisity test has applied a scatter diagram technique. When a scatter diagram does not have any clear specific patern and the dots have been scattering at the upper side and below 0 at $\mathrm{Y}$, so that there is not any heteroskedastisity happened. Graph model on the picture 3 could be provided since it has some independent variables.

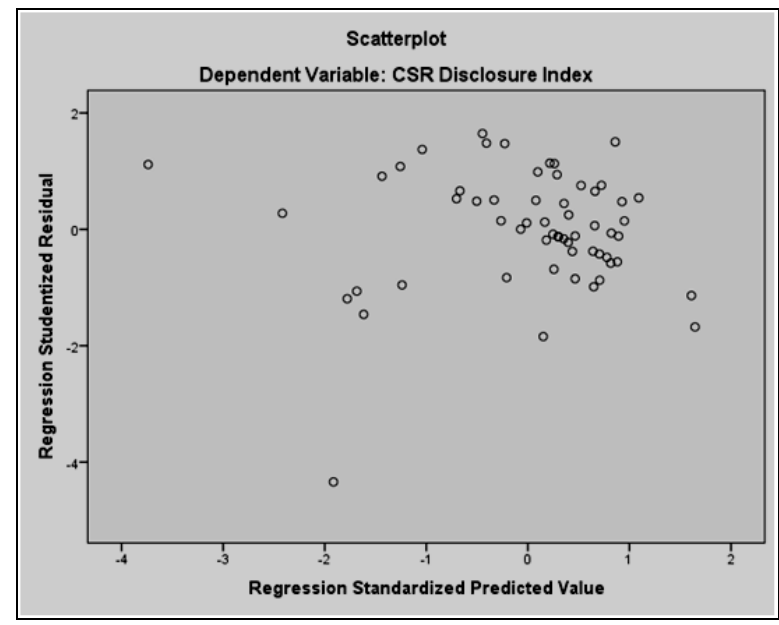

Source: Output SPSS 22.00 (2015)

\section{Picture 3}

Result of scatter diagram test

Instead of applying the diagram-scatter analysis to test heteroskedastisity, glejser test can be applied. Glejser test can be done by using the regression analysis of residual absolute value (AbsUi) against the independent variables and other variables (Total asset variable and leverage) refers to the following regression formula;

$$
U i \mid=\alpha+\beta X i+\mu i
$$

When $\beta$ is significant, it indicates that heteroskedatidity problems has occurred.

Table: 4 Glejser test

\begin{tabular}{|c|c|c|c|c|c|c|}
\hline \multicolumn{7}{|c|}{ Coefficients $^{\mathrm{a}}$} \\
\hline \multirow[b]{2}{*}{ Mode } & & \multicolumn{2}{|c|}{ Unstandardized Coefficients } & \multirow{2}{*}{$\begin{array}{c}\begin{array}{c}\text { Standardized } \\
\text { Coefficients }\end{array} \\
\text { Beta } \\
\end{array}$} & \multirow[b]{2}{*}{$t$} & \multirow[b]{2}{*}{ Sig. } \\
\hline & & $\mathrm{B}$ & Std. Error & & & \\
\hline \multirow[t]{7}{*}{1} & (Constant) &,- 037 &, 056 & &,- 655 & .516 \\
\hline & $\begin{array}{l}\text { Proporsi Kepemilikan } \\
\text { Institusional }\end{array}$ &,- 005 & 038 &,- 016 &,- 121 &, 904 \\
\hline & Ukuran Dewan Komisaris &, 001 &, 004 &, 025 &, 139 & 890 \\
\hline & $\begin{array}{l}\text { Proporsi Komisaris } \\
\text { Independen }\end{array}$ & 247 &, 086 &, 387 & 2,860 & .006 \\
\hline & Ukuran Komite Audit &,- 002 &, 016 &,- 016 &,- 115 & ,909 \\
\hline & Kualitas Audit &,- 004 &, 015 &,- 051 &,- 302 & .764 \\
\hline & Leverage &, 002 &, 005 & .049 &, 380 &, 706 \\
\hline
\end{tabular}

Source: Output SPSS 22.00 (2015) 
Based on table 4 aforementionned, in general the related variables is not significant at the level of 0.05 significant level, so that it could be concluded that there is not any heteroskedastisity problem happened refers to its residual data.

\section{Multicolinearization test}

The test has been done to identify VIF (Varian Inflated Factor)value and tolerance value refers to the table 5 as follows:

Table 5

Result of Multicolinearization test

\begin{tabular}{|l|c|c|}
\hline \multicolumn{1}{|c|}{ Variabel } & Tolarance & VIF \\
\hline Proporsi kepemilikan institusional & 0,969 & 1,032 \\
\hline Ukuran dewan komisaris & 0,521 & 1,921 \\
\hline Proporsi komisaris independen & 0,905 & 1,105 \\
\hline Ukuran komite audit & 0,816 & 1,225 \\
\hline Kualitas audit & 0,568 & 1,760 \\
\hline Leverage & 0,976 & 1,024 \\
\hline
\end{tabular}

Source: Output SPSS 22.00 (2015)

Based on the result of multicolonization test on the table 5 aforementioned, it explains that VIF value of each variable is $<10$ and tolerance value is $>0.1$, it is concluded that the regression model is free from multicolonization among the independent variables.

After regression model has passed the classical assumption test, the following step is hypothesis test to prove scientifically that the influence of Good Corporate Governance and Quality against the disclosure of Corporate Social Responsibility have happened, then determinant coefficient test ( $R$ Square), simultaneous significant test (F-test) and individual parameter significant test (t-test)have to be done.

\section{Result of Hypothesis Test}

\section{Determinant Coefficient Test $\left(\mathbf{R}^{2}\right)$}

Determinant Coefficient Test is to measure a strong influence has happened between independent and dependent variables. The result of determinant correlation test is on table 6 as follows:

Table 6 Coefficient result

\begin{tabular}{|l|r|r|r|r|}
\hline \multicolumn{5}{|c|}{ Model Summary } \\
\hline Model & R & R Square & Adjusted R Square & Std. Error of the Estimate \\
\hline 1 &, $608^{\mathrm{a}}$ &, 369 &, 297 & \\
\hline $\begin{array}{l}\text { a. Predictors: (Constant), Leverage, Proporsi Kepe milikan In stitusional, Kualitas Audit, Ukuran } \\
\text { Komite Audit, Proporsi Komisaris Independen, Ukuran Dewan Komisaris } \\
\text { b. Dependent Variable: CSR Disclosure Index }\end{array}$ \\
\hline
\end{tabular}

Source: Output SPSS 22.00 (2015)

Refers to the table 6 aformentioned, it explains that $R$ value is 0.608 showing that multiple correlation between independent variable and dependent variable is $60.8 \%$. $\mathrm{R}$ square $=0.369$ refers to $36.9 \%$ changes of the variable of the disclosure of corporate social responsibility that could be explained by the variable of the proportion of the institutional ownership, the size of commissioner board, the proportion of independent commissioners, the size of audit committee, audit quality and leverage. The remaining of $63.1 \%$ has been explained by other variables which is they are not being research. 


\section{F-test}

F-test or Annova to discover whether all the independent variables including in this model have been influencing in line with or simultaneously upon the dependent variables.

Result of F-test herebelo:

Table 7 Result of F-Test

\begin{tabular}{|c|c|c|c|c|c|c|}
\hline \multicolumn{7}{|c|}{ ANOVA $^{\mathrm{b}}$} \\
\hline Model & & Sum of Squares & Df & Mean Square & $\mathrm{F}$ & Sig. \\
\hline \multirow{3}{*}{1} & Regression &, 143 & 6 & \multirow{3}{*}{$\begin{array}{l}, 024 \\
, 005\end{array}$} & \multirow[t]{3}{*}{5,077} & \multirow[t]{3}{*}{, $000^{2}$} \\
\hline & Residual & 244 & 52 & & & \\
\hline & Total & 387 & 58 & & & \\
\hline \multicolumn{7}{|c|}{ a. Predictors: (Constant), Leverage, Proporsi Kepemilikan Institusional, Kualitas Audit, Ukuran } \\
\hline \multicolumn{7}{|c|}{ Komite Audit, Proporsi Komisaris Independen, Ukuran Dewan Komisaris } \\
\hline b. Depe & ndent Variable & SR Disclosure Ind & & & & \\
\hline
\end{tabular}

Source: Output SPSS 22.00 (2015)

Based on F-test or Anova test analysis, it has identified that $p$-value is 0.000 refers to significant value $<\alpha_{5} \%$ indicating a significant influence between good corporate governance variable and audit quality variable against the disclosure of corporate social responsibility.

\section{3. t-test}

T-test to discover any influence of each independent variable happened partially against the dependent variables. T-test result is on table 8 here below:

Table 8 t-test

\begin{tabular}{|c|c|c|c|c|c|c|}
\hline & & \multicolumn{2}{|c|}{$\begin{array}{l}\text { Unstandardized } \\
\text { Coefficients }\end{array}$} & \multirow{2}{*}{$\begin{array}{c}\begin{array}{c}\text { Standardize } \\
\text { d } \\
\text { Coefficients }\end{array} \\
\text { Beta }\end{array}$} & \multirow[b]{2}{*}{$\mathbf{t}$} & \multirow[b]{2}{*}{ Sig. } \\
\hline \multicolumn{2}{|c|}{ Model } & B & $\begin{array}{l}\text { Std. } \\
\text { Error }\end{array}$ & & & \\
\hline 1 & (Constant) & 969 &, 091 & & 10,675 &, 000 \\
\hline & Proporsi Kepemilikan Institusional & 031 & 061 & 057 &, 514 & 610 \\
\hline & Ukuran Dewan Komisaris &,- 002 &, 006 &,- 060 &,- 395 & 694 \\
\hline & Proporsi Komisaris Independen &,- 657 & ,139 &,- 547 & $-4,726$ &, 000 \\
\hline & Ukuran Komite Audit & 025 &, 025 &, 119 &, 979 &, 332 \\
\hline & Kualitas Audit & ,026 &, 024 & , 159 & 1,086 & ,282 \\
\hline & Leverage &,- 022 & 007 & $-3,28$ & $-2,944$ & 005 \\
\hline
\end{tabular}

a. Dependent Variable: CSR Disclosure Index

Source: Output SPSS 22.00 (2015)

According to t-test result on table 8 , it explains that:

a. $p$-value of institutional ownership proportion variable is 0.610 . It explains that $p$-value is higher than probability value $(0.610>0.05)$, so that $H_{1}$ is acceptable which is the variable of institutional ownership proportion has not influenced significantly upon the disclosure of CSR.

b. P-value of the variable of commissioner board members is 0.694 . It explains that $p$-value is higher than probability value $(0.694>0.05)$ and $\mathrm{H}_{2}$ is acceptable which is the variable of commissioners board member has not influenced significantly upon the disclosure of CSR.

c. P-value of the variable of the proportion of independent commissioner is 0.000 . It explains that $p$-value is lower than probability value $(0.000<0.05)$ indicating that $\mathrm{H}_{3}$ is acceptable 
which is the variable the proportion of independent commissioner has influenced negatively and significantly upon the disclosure of CSR.

d. P-value of the variable of the size of audit committee members is 0.332 . It explains that $p$ value is higher than probability value $(0.332>0.05)$ indicating the $\mathrm{H}_{4}$ is not acceptable which is the variable of the size of audit committee members does not have any significant influences upon the disclosure of CSR.

e. P-value of the variable of audit quality is 0.282 . It explains that $p$-value is higher than its probability value $(0.282>0.05)$ indicating that $\mathrm{H}_{5}$ is not acceptable which is the variable of audit quality does not have any significant influences upon the disclosure of CSR.

f. P-value of control variable of leverage is 0.005 . It explains that $p$-value is lower than its probability value ( $p$-value $<0.05)$ indicating that leverage is able to be considered as a controll variable against the disclosure of CSR.

The result of descriptive statical test has been indicating the level of the disclosure of CSR information is $80.34 \%$ which is quite high. The simultaneous examination has indicated that the influences of the variable of good corporate governance and audit quality upon the CSR disclosure is $R^{2}=0.369$ or $36.9 \%$ of the proportion of the institutional ownership, commissioners board members, independent commissioners proportion, audit committee member, audit quality and leverage as a controlling variable could describe their influences upon the variable of the disclosure of corporate social responsibility. The remaining of $63.1 \%$ has been influenced by other evaluated variables.

According to the result of hypothesis test which is declared on table 8 aforementioned, the description of the related hypothesis is in line with the previous research either its theory or its result.

1. The result of this research has identified that the proportion of the institutional ownership has not been influencing significantly upon the disclosure of corporate social responsibility refers to the significant value of 0.610 which is higher than a significant level $0.05(5 \%)$. It explains that a hypothesis defining the proportion of institutional ownership has not influenced upon the disclosure of the corporate social responsibility. The result of this research is not in line with Anggraini's research (2006) where the proportion of the institutional ownership has influenced upon the disclosure of company social responsibility. As the institution has the power to interfere the activity of the operational company then the management is influenced upon making a decision which is at the end the investor does not have any function to reduce a conflict happened with the agency. Nevertheless, the result of this research has been at least in line with the research of Andayani, et al (2008) and Hapsoro (2012) defining that the proportion of the institutional ownership has not been influencing upon the disclosure of corporate social responsibility. Furthermore, big proportion of the institutional ownership would not insist the company to desclose the CSR in detail in its annual report, even though at average $80.34 \%$ of manufacturing companies registered in $\mathrm{BEI}$ has been disclosing the information about their corporate social responsibility.

2. The result of this research has indicated that the size of the commissioners board has not been influencing significantly upon the disclosure of its corporate social responsibility refers to its signifant value of 0.694 which is higher than the significant level $0.05(5 \%)$. The result of this research is not in line with the research of sembiring (2005) Akhtaruddin, et.a. (2009) and Hapsoro (2012) identified that the more member of the commissioners board the easier monitoring and controlling the CEO would be since the total member of commissioners board obviously has been influencing upon the disclosure of company social responsibility. It is identified that the composition of commissioners board which is 4.32 persons at average unable to dominate monitoring effectively the disclosure of the corporate social responsibility. Meanwhile, the size of the commissioner board could not guarantee a better controlling mechanism as it is not the key factor.

3. The result of this research has indicated that the proportion of independent commissioners has a significant influence to disclose the corporate social responsibility refers to a significant value 0.000 explaining that it is below a significant level $0.05(5 \%)$. The result of this research is in line with the legitimate theory, especially the research done by Andayani, et.al (2008) and Forker (in Said, et al, 2009) identified that the proportion of independent commissioners has a positive influence upon the disclosure of CSR It was discovered that the average of the proportion of independent commissioners at the manufacturing companies registered in BEI which is $39.93 \%$ 
is not only to apply the regulation of Bapepam and Indonesia Stock-Exchange No. 1-A dated on 4th July 2004 regarding the minimum requirements about the proportion of the independent commissioners member, but also to select and to appoint the independent commissioners effectively refers to their decision to make objectively to protect the whole stakeholders in monitoring the disclosure of the CSR information. It explains that the less proportion of independent commissioners the more focus to insist the management to improve the quality of the information disclosure about its corporate social responsibility will be.

4. This research has been indicating that the total of audit committee member has not influenced significantly upon the disclosure of corporate social responsibility itself refers to a significancy value of 0.300 which is higher than $0.05(5 \%)$ significant level. It explains that there is hypothesis declaring the total member of audit committee has not influenced upon the disclosure of the corportate social responsibility of the companies in Indonesia. This research has been in line with the research of Sabeni \& Norhadi (2002) and Akhtaruddin et.al (2009) identified that there has not been any influence between the total member of audit committee and CSR happened. It explains that the total member of audit committee will never influence the disclosure of the information about CSR because it could not create an effective controlling mechanism against the company management.

5. The research has been indicating that the audit quality has not influenced significantly upon the disclosure of corporate social responsibility refers to its significant value 0.119 which is higher than the significant level $0.05(5 \%)$. It has been assumed that most samples of the companies have been audited by non-big four KAp which is $56 \%$ at. This research is not in line with the research of Subroto (2002) and Hapsoro (2012) defined that the higher the audit quality the more details of the disclosure of corporate social responsibility will be refers to their company annual report.

The result of this research has indicated that its leverage has a significant influence upon the disclosure of corporate social responsibility refers to its 0.00 significant value which is it is lower than a significant level $0.05(5 \%)$. It could be defined that the leverage variable has been in compliance with the influence of dependent variable (corporate governance and audit quality) against the disclosure of corporate social responsibility. Therefore, the manufacturing companies in Indonesia that have been the samples of this research are fully aware about the disclosure of corporate social responsibility within the company itself stated on its annual report.

\section{CONCLUSIONS AND RECOMMENDATIONS}

Based on the result of this research referfs to the previous chapters, it concludes that:

1. The proportion of the institutional ownership has not influenced significantly upon the disclosure of the corporate social responsibility within the company.

2. The total member of commissioner board has not influenced significantly upon the disclosure of corporate social responsibility within the company.

3. The proportion of the independent commissioners has a significant negative influence upon the disclosure of corporate social responsibility.

4. The total member of an audit committee has not influenced significantly upon the disclosure of corporate social responsibility.

5. An Audit quality has not influenced significantly upon the the disclosure of corporate social responsibility.

\section{SUGGESTIONS}

1. For the government, it is expected to continue improving the regulations about the corporate social responsibility in Indonesia either at government sectors of private sectors, especially for the manufacturing companies having a potential reason to jeopardize the the environment which is becoming more and more dangerous and it has to be controlled.

2. For the companies, manufacturing companies are expected to be registered in BEI in order to be more opened to disclose their information about their corporate social responsibility in their annual report. 
3. For next researchers, they are expected to apply a long-term periode controlling and to add more samples. They should have to apply other indicator to disclose the CSR which is in compliance with the companies characteristics in Indonesia. Furthermore, they could add or apply other variables to evaluate its influences upon the disclosure of corporate social responsibility such as the institution ownership, foreigner ownership, total of the meeting between the commissioners board and audit committee, competency of commissioner board and audit committee, and other variables of good corporate governance.

\section{REFERENCES}

Akhtaruddin, M., M. Hossain, dan L. Yao (2009). Corporate Governance and Voluntary Disclosure in Corporate Annual Reports of Malaysian Listed Firms. JAMAR. 7 (1), 1-20.

Alim, M. Nizarul, et al. (2007). Pengaruh Kompetensi dan Independensi terhadap Kualitas Audit dengan Etika Auditor sebagai Variabel Moderasi. Simposium Nasional Akuntansi X. AUEP-08 (1-26).

Andayani, R., Lisawati, Y., dan Maimunah. (2008). Corporate Social Responsibility, Good Corporate Governance and the Intellectual Property: an External Strategy of The Management to Increase the Company's Value. Makassar: National Management Research.

Anggraini, Fr. Reni Retno. (2006). Pengungkapan Informasi Sosial dan Faktor-Faktor yang Mempengaruhi Pengungkapan Informasi Sosial dalam Laporan Keuangan Tahunan (Studi Empiris pada Perusahaan-Perusahaan yang Terdaftar Bursa Efek Jakarta). Simposium Nasional Akuntansi IX Padang, 23-26 Agustus 2006.

Badan Pengawasan Keuangan dan Pembangunan. (2000). Pembentukan Komite Audit. Surat Edaran Bapepam No.SE-03/PM/2000.

Badan Pengawasan Keuangan dan Pembangunan. (2011). Pembentukan dan Pedoman Pelaksanaan Kerja Komite Audit. Keputusan Ketua Bapepam Peraturan Nomor IX.I.5.

Carcello, J. V., Terry L. Neal , Zoe-Vonna Palmrose \& Susan Scholz. (2011). CEO Involvement in Selecting Board Members, Audit Committee Effectiveness, and Restatements. Contemporary Accounting Research, 28.

De Cleyn, Sven H. (2008). Compliance of Companies with Corporate Governance Codes: Case Study on Listed Belgian SMEs"? Journal of Business Systems, Governance and Ethics, 3 (1).

De Graaf, Frank Jan \& Stoelhorst, J.W. (2010). The Role of Governance in Corporate Social Responsibility: Lessons from Dutch Finance. Business \& Society.

Egon Zehnder International. (2000). Corporate Governance and the Role of The Board of Directors.

Guthrie, J., Cuganesan, S., \& Ward, L. (2006). Legitimacy Theory: A Story of Reporting Social and Environmental Matters within The Australian Food and Beverage Industry. Paper Presented at the $5^{\text {th }}$ Asian Pasific. Interdiciplinary Research in Accounting (APIRA) Conference, Aucland - New Zealand.

Hadi, Nor. (2011). Corporate Social Responsibility (CSR). Edisi ke-1. Jakarta: Graha IImu.

Hadi, Nor dan Arifin Sabeni. (2002). Analisa Faktor-Faktor yang Mempengaruhi Luas Pengungkapan Sukarela dalam Laporan Tahunan Perusahaan Go Publik di Bursa Efek Jakarta. Journal Maksi, 1. Agustus 2002. 
Hapsoro, Dodi (2012). Pengaruh Corporate Governance dan Kualitas Audit terhadap Pengungakapan Corporate Resposibility. Jurnal Akuntansi dan Manajemen, 23 (3), 199215.

Jensen, M. \& W. Meckling. (1976). Theory of the Firm: Managerial Behaviour, Agency Cost, and Ownership Structure. Journal of Financial Economics, 305-360.

Kallunki, Juha-Pekka, Henrik Nilsson_and Mikko P.Zerni. (2011). The Entrenchment Problem, Corporate Governance Mechanisms Firm Value. Contemporary Accounting Research, Forthcoming.

Koh, P. (2003). On the Association between Institutional Ownership and Aggressive Corporate Earnings Management in Australia". The British Accounng Review, 35.

Komite Nasional Kebijakan Governance. (2004). Pedoman Umum Good Corporate Governance di Indonesia. Jakarta.

Nik Ahmad, Nik Nazli., Mailah Sulaiman. (2004). Environmental Disclosure in Malaysian Annual Reports: A Legitimacy Theory Perspective. International Journal of Commerce \& Management. 14, (1).

Nurlela, Rika dan Islahudin. (2008). Pengaruh Corporate Social Responsibility terhadap Nilai Perusahaan dengan Persentase Kepemilikan Manajemen sebagai Variabel Moderating. Simposium Nasional Akuntansi X.

Ramanarayanan, S. and Snyder J. (2012). Information Disclosure and Firm Performance: Evidence from the Dialysis Industry. Working Papers Series.

Rustiarini, W. (2010). Pengaruh Corporate Governance pada Hubungan Corporate Social Responsibility dan Nilai Perusahanan. Simposium Nasional Akuntansi XIII. AKPM_12.

Ryngaert, Cedric and Holly Buchanan. (2011). Member State Responsibility for the Acts of International Organizations. Utrecht Law Review, 7 (1), 131-146.

Said, R., Yuserrie Hj Zainuddin, dan Hasanah Haroh. (2009). The Relationship between Corporate Social Responsibility and Corporate Governance Characteristics in Malaysian Public Listed Companies. Social Responsibility Journal, 5 (2), 212-227.

Subroto, P.H. (2002). A Correlational Study of Corporate Social Responsibility and Financial Performance an Empirical Survey Toward Ethical Business Practice in Indonesia. Dissertation Capella University.

Sugiyono. (2014). Metode Penelitian Kombinasi (Mixed Methods). Cetakan ke-5, Bandung: CV. Alfabeta.

Suherman, Rahma, W. dan Buchdadi D.A. (2011). Firm Performance, Corporate Governance, and Executive Compensation in Financial Firms: Evidence from Indonesia. Working Paper Series.

Susiana \& Arleen Herawaty. (2007). Analisis Pengaruh Independensi, Mekanisme Corporate Governance, dan Kualitas Audit terhadap Integritas Laporan Keuangan. Simposium Nasional Akuntansi X, 1-31.

Untung, Hendrik B. (2008). Corporate Social Responsibility. Jakarta: Sinar Grafika. 